\title{
PERSONALITY ORIENTED SYSTEM OF STRENGTHENING OF STUDENTS’ PHYSICAL, PSYCHIC
} AND SOCIAL-MORAL HEALTH

Kudryavtsev M.D. ${ }^{1,3}$, Kopylov Yu.A. ${ }^{2}$, Kuzmin V.A. ${ }^{1}$, Ionova O.M. ${ }^{4}$, Yermakova T.S. ${ }^{4}$

${ }^{1}$ Siberian Federal University (SibFU), Krasnoyarsk, Russia

${ }^{2}$ The Federal State Scientific Institution of Russian Academy of education "The Institute of Age Physiology", Moscow, Russia

${ }^{3}$ Siberian State Aerospace University, Krasnoyarsk, Russia

${ }^{4}$ H.S. Skovoroda Kharkiv National Pedagogical University

\begin{abstract}
Purpose: to work out content of individualized trainings, permitting to correct deviations in different aspects of physical, psychic and social-moral health of higher educational establishments' students. Material: in experiment 105 boy students of 20-24 years' age participated. All students gave conscious consent to participate in experiment. The trainings were practice 4 times a week, 45 minutes each. Results: it is interesting that change of different personality's features is rather long process, which in some aspects resist to changes. We showed approaches to training vitally important skills and abilities, required for adaptation to modern social cultural medium; to the simplest techniques of organization of independent health related physical culture trainings; to means of health strengthening, formation of knowledge on health related physical culture. We developed personality-oriented system of formation of psychic and social-moral health. Conclusions: the worked out approach permits to achieve real positive psychic and socially important qualities of student's personality during one academic year.
\end{abstract}

Key words: health, physical culture, physical training, psycho-regulation, breathing gymnastic.

\section{Introduction}

Recent years there have been observed worsening of higher educational students' physical, psychic and socialmoral health $[3,17]$. The found deviations in health are the results of many reasons: reduction of motor functioning against the background of increased academic loads; reduction of every day motor activity; violation of healthy life style rules [25].

Study of higher school students' psycho-physical indicators [16] showed that in most cases there is found weak condition of motor qualities with unsatisfactory state of different psychic indicators [14]. To avoid this situation it is necessary to implement different forms of health related physical culture, special, correcting and rehabilitating activity in system of higher educational establishment students' physical education. However, in this respect, pedagogues of higher educational establishments face great difficulties [6] because of absence of developed and scientifically grounded program of such trainings.

At present time problems of physical education of higher educational establishments' students are still more acute [37]. As it was found in [8], traditional system of physical education does not realize the tasks of health formation of educational establishments' students to the fullest extent. In such situation it is necessary to develop pedagogic technology [15] oriented on training of psycho-physical, social-moral health and important for learning students' qualities [5].

Formation of students' psycho-physical health can be realized in different directions. In opinion of V.V. Ismiyanov [13] such approach implies qualitative changes of students' physical fitness (improvement of motor qualities: general endurance, speed endurance, strength, flexibility, quickness), psycho-emotional state (personality's qualities, communicability, will power, feelings and emotions). It results in significant improvement of social status and lifebuilding in system of higher education and further professional functioning of students. In such cases it is very important to determine students' ability to self-cognition of own psycho-physical and motor potentials [4]. Not less important is express-assessment of students' physical health level [27], substantiation of the used tests [28, 32].

The state of students' social-moral health is determined by several factors. A.A. Opletin and V.D. Panachev [21] found that students' will efforts facilitate stability of personality, psychic and physical health and increase of life tonus as well as workability and optimism. In process of pedagogic auto-training practicing at physical culture lessons psychological settings for formation of self development competence that facilitates formation of student's professional orientation. In the process of future functioning psychological settings are fixed and transform in social. In other works [19] it is shown that in the structure of students' temper low level of demand in mastering of objective world and strives for mental and physical labor prevails. With it is noted that there are good indicators of social activity and communicability.

Training of students' significant for studying qualities requires appropriate content of their psychological and psycho-physical fitness. The offered by V.V. Pichurin [24] content of students' such training is effective in respect to reduction of individual anxiety. The author points that application in physical culture lessons significant for boys kinds of sports - weight lifting and power lifting and for girls - aerobics and sakhadja yoga statistically significantly influenced

\footnotetext{
(๖) Kudryavtsev M.D., Kopylov Yu.A., Kuzmin V.A.,

lonova O.M., Yermakova T.S., 2015

doi:10.15561/20755279.2016.0306
} 
on reduction of individual anxiety. For achievement of the set aims Yu.A. Osipov et al. [22] recommend using technologies of formation of social physical culture-sports medium, rating system of assessment of students' sports achievements; individualized and specialized programs of students' physical education.

In other works demand in the following is noted: rising of psychological comfort in students' groups in conditions of increase of their physical activity [38]; application of social constructive educational model for students' training [30]; demand in consideration of social demographic factors' influence on formation of students' healthy life style [33]; determination of health levels and physical condition, physical workability and physical fitness; students' psychic state $[1,26,31]$; constant monitoring of students' health condition [29, 32, 40]; appropriate substantiation of tests' usage [34].

In our previous researches we determined that content of additional (health related) physical culture training envisages prevailing orientation on health improving, general developing and sport-recreational tasks. With it, first attention is paid to formation of physical, psychic and social-moral health [15]. In such cases it is necessary to use adequate forms of control over students' health [32] with their appropriate substantiation [35]. Besides, it is necessary to consider the presence of possible deviations in students' health [36,39]. Earlier we found that in training of future pedagogues it is important or realize salute-genetic approach [12]. This approach is based on anthroposophically oriented methodological principles and facilitates healthy, holistic development of students. With such approach main directions of students' training (academic learning, training by life experience, internal spiritual development) are oriented on activation of human internal intentions; awakening of students' will to study during all life; stimulation of independent work on own perfection in professional and personal spheres.

Testing of students elucidate a little individual peculiarities of such category. Such important aspects as physical, psychic and social-moral health of students are still out of scientists' interests. The absence of such data seriously hinders formation of students' comprehensive personalities and their social adaptation in modern society.

In connection with the above said it seems to be important to seek innovative approaches to new methodic and technologies' working out in the process of students' education and teaching. The purpose of such search is physical rehabilitation and pedagogic correction of students' health by means of health related physical culture and elements of sports activity [5].

Hypothesis: personality-oriented system of students' health formation shall consider their individual features. Such approach will permit to solve the following tasks:

- teaching to vitally important skills, required for adaptation in modern social-cultural medium;

- training the simplest techniques of organization of independent health related physical culture training;

- teaching to methods of health strengthening; formation of knowledge in health related physical culture.

The purpose of the research: is to work out personality oriented system of formation of students' physical, psychic and social-moral health.

The tasks of the research:

1. To work out complexes of physical exercises for correction of deviation in physical, psychic and social health of students.

2. To assess effectiveness of complexes of physical exercises for correction of deviation in physical, psychic and social health of students.

\section{Material and methods}

Participants: in experiment 105 boy students of 20-24 years' age participated. All students gave conscious consent to participate in experiment. The trainings were practiced 4 times a week, 45 minutes each.

Procedure:

Pedagogic experiment was conducted during one academic year on the base of pedagogic faculties of higher educational establishments. Experiment involved pedagogues, medical workers, specialists in physical education.

At each training, one from four training complexes was worked at:

1. Block "Attention", block "Gymnastic for eyesight" and block "Breathing gymnastic".

2. Block "Carriage" and block "Prophylaxis of flat-footedness".

3. Block "General physical training".

4. Block "Prophylaxis of cold" and block "Psycho-regulation".

Testing was fulfilled twice a week: at the beginning and at the end of pedagogic experiment.

Organization of health related exercises' training considered three main principles:

- Principle of consequent teaching from simple to complex;

- Principle of movement's temp and duration correspondence to targets and tasks of training process safety;

- Principle of safety of educational process.

Assessment of physical-metrical indicators: we studied right hand strength, kg; left hand strength, kg; vital capacity of lungs, 1; body length $(\mathrm{cm})$ and mass $(\mathrm{kg})$; heart beat rate in rest (b.p.m.); chest circumference (cm) [18].

Assessment of significant for studying indicators: it was fulfilled by pedagogues by five points' scale. They assessed formation of interest to studying, mental workability, aggressiveness, emotional stability, degree of attention concentration, assiduity [10]. 
Assessment of formation of interest to physical culture and sports practicing: was fulfilled by students, who estimated each motive: health strengthening, communication, strive to be courage and resolute, preparation for future activity; self satisfaction with activity, self assertion and self realization by five points' scale [7]:

1. I practice physical culture for health strengthening.

2. I practice physical culture to communicate more with my fellow students.

3. Physical culture permits for me to manifest courage and resolution.

4. I practice physical culture to prepare for professional functioning.

5. I practice physical culture, because I like sports trainings.

6. I practice physical culture and sports to defeat my fellow students.

After it we calculated mean value of accounted points.

Assessment of formation of socially significant qualities [20]: in questionnaire students assessed statements about their qualities by five points' scale. In total 24 statements were used in questionnaire.

1. Respect most of people and my classmates;

2. I develop ability to see difficulties of other people and actively help them;

3. I am ready to sacrifice my interests in favor of collective;

4. I help my peers, not waiting for praise or award;

5. I want that my labor would be useful for people;

6. I have careful attitude to man made things;

7. I always strive to do my best in any work;

8. I strive to cope with all difficulties in work by myself;

9. I often invent my own approach to business, own means of achievement of the set target;

10. I like to offer and realize new deeds;

11. I am a purposeful person;

12. I am able to work in full strength for long time;

13. I am ashamed if I lazy to help my parents or friend;

14. Discontent with myself helps me to fight with my drawbacks;

15. I am responsible in respect to class interests, mutual success;

16. I feel sympathy toward peers, who are not able to do something;

17. I fulfill any unpleasant work, if it is useful for people;

18. I have careful attitude to animals, vegetation, nature;

19. I am scrupulous and diligent in any business;

20. I like independent, difficult work;

21. I like to do any work interesting and useful for myself and other people;

22. I like to master new activities, new knowledge and new skills;

23. I used to outline the main in any business without distracting to less important tasks;

24. I am able to control my temper and be tolerant in conflicts with people.

After calculation of collected by every student points we determined average level of social qualities' formation: activity, moral position (questions 1,2,13,14), collectivism (questions 3, 4, 15, 16), civic consciousness - strive to be useful for people (questions 5, 6, 17, 18), diligence (questions 7, 8, 19, 20), creative activity (questions 9, 10, 21, 22) and will quality (questions $11,12,23,24$ ).

Assessment of motor qualities' formation: assessment of main motor qualities (strength, quickness, dexterity, flexibility, peed-power indicators, general endurance) we used tests for the following:

1) Quickness of movements - 30 meters' run from high start;

2) Dexterity - "shuttle run" $3 \times 10$ m;

3) Speed-power indicators - long jump from he spot;

4) Strength - chin ups;

5) Flexibility - forward bending from sitting position;

6) General (aerobic) endurance - run during 6 minutes.

Assessment of healthy life style indicators: components of healthy life style (in percents) were assessed with questioning method. Students informed about usage of the following components: morning exercises; independent practicing of physical exercises in any form; attendance of sport circle; hardening; normal night sleep. Every answer was assessed by five points' scale. The sum of collected points was calculated by eight test questions. Then mean value calculated.

Content of trainings: was oriented on strengthening of health different aspects [9].

\section{Complex 1}

\section{Block “Attention” (25 minutes):} side forward.

Walking on narrow support: gymnastic balance beam, gymnastic bench; walking by marks - with back forward,

Exercises for coordination and balance: juggling by big (volleyball) and small (tennis) balls (2-3 balls); moving on inclined, limited support with and without an object on head. 
Exercise on gymnastic balance beam: walking with different amplitude of movements, with acceleration; walking with legs' waving and turns on toes; stance on toes; forward jump by pushing with two feet; balancing on one foot; squat with hands on floor; jumps down.

Multiple passes of basketball ball in pairs - up to 3-5 minutes. making step.

Catching of volleyball (tennis) ball: from floor, rolling ball (standing on the spot and in motion), flying high,

Throw of basketball ball in basket by two hands from below.

Throw of small balls to target from the spot and in motion.

\section{Bock "Gymnastic for eyesight" (10 minutes)} muscles.

The exercises are fulfilled in convenient sitting position with head resting on chair's back and maximally relaxed

"Eyeball movements to the right and to the left" - shall be fulfilled without excessive tension, as slow as possible.

"Eyeball movements upwards and downwards" - shall be fulfilled with maximal amplitude with head upright. Repeat 4-6 times to each side. Close eyes and relax muscles for 30-40 seconds.

"Fixing of eyes on tip of nose" - shall be fulfilled with maximally relaxed muscles and calm, even breathing, during 10-20 seconds. After exercise, close eyes and relax body muscles for 30-40 seconds. If student feel fatigue, rest time can be prolonged.

"Eyes' rotation" - rotate eyes by circumference: first clockwise, then - counterclockwise. Make 3 rotations to each side. Rotations shall be smooth, without jerks. Head shall be unmovable. Relax muscles for 30-40 seconds.

"Blinking": quickly press and part eyelids (blink) during 15-20 seconds. After it, close eyes and relax muscles for 30-40 seconds. This exercise is useful after durable reading; in breaks between exercises for eyesight.

\section{Block "Breathing gymnastic" [2] (10 minutes)}

Lungs' ventilation: deeply inhale and exhale as quickly as possible. Make 5-7 cycles. After exercise, relax muscles in lying position with closed eyes.

Cleaning breathing: take main stance and deeply inhale through nose, make 2-3 seconds' pause. Exhale by "portions" (3-4 portions in one cycle).

Expansion of chest: in main stance stretch arms forward. Fulfill deep inhales/exhales: during inhale move arms backward aside; at exhale - return arms in forward position. Repeat 10-12 times. This exercise expands chest that is very important for good breathing. Children with narrow chest have weak breathing muscles. This exercise helps to form elementary skills of rational breathing movements.

\section{Complex 2}

Block "Carriage" (35 minutes)

Hatha Yoga exercises [11].

Bow posture: lie on abdomen, feet together. Bend legs and seize ankles. Arms shall be stretched. Try7 keep legs and feet together. Slowly raise shins. Backbend so that only abdomen is in contact with floor. Look upward. Keep the posture for $10 \mathrm{sec}$. and slowly take initial position. Relax all body. The posture is useful for all body, especially for backbone and abdomen; it perfectly eliminates defects of carriage.

Stand on one foot: - initial position - stand on one foot with left ankle on the base of right thigh. Or you can place left sole on inner surface of right thigh. Keep palms together in front of chest. Keep balance. Slowly raise palms above head, keeping them together. Part hands aside like tree branches. Arms shall be stretched. Slowly come out of posture and repeat it on other foot. This exercise forms correct carriage, develops arms, girdle and back muscles; improves balance.

Posture of armchair: stand upright with feet parted by approximately $40 \mathrm{~cm}$. Stretch arms forward, hands are relaxed, hanging down. Bend legs in knees and squat a little. Imagine that you are sitting in invisible armchair. Keep posture as long as possible. Upper part of legs will be tensed. It is an excellent exercise for legs and back's muscles, as well as for handsome carriage.

Swallow posture: bend forward from main stance. Raise right leg parallel to floor, stretching arms forward. Arms, torso and right leg make straight line. Keep posture for 20-30 seconds and take initial position. Repeat exercise with rising left leg. This exercise trains back muscles as well as muscles of thigh back side and girdle.

Forward bent in sitting position: lie on back, keep feet together. Slowly take sitting position, bend forward as low as possible. Seize ankles. Drop head and relax. Keep posture about 20 seconds. Come out of posture: first sit upright and then, lie on back. Place arms along torso with palms upward. Feet are a little apart.

Cobra posture: lie on abdomen, keep legs together. Place palms on floor at shoulder level. Slowly raise and bend as much as possible head and chest; keep abdomen in contact with floor. Look upwards. Keep posture about 20 sec. Breath normally. Then low slowly first chest and then head. This exercise strengthens back muscles and eliminates shifts in backbone.

Triangle: from main stance part feet wider than shoulders by jump. Raise arms aside at shoulder level with palms downwards. Turn right and left feet to the right - left leg is stretched. Bend torso to the right and touch right ankle with right palm (possible to place right palm on the floor). Stretch left arm upwards. Keep posture for 30-40 seconds. Breathing 
shall be even and deep. Take initial position and fulfill the exercise to other side. This exercise increase hip joints and backbone's mobility; expands chest.

Forward lunge with arms upwards: From main stance raise arms upwards - palms together. Make deep forward lunge with right leg; raise head and look at palms. Angle in right knee shall be $90^{\circ}$, left leg is stretched. Keep posture for 20-30 seconds. Breathing is free. This exercise increase tonus and strengthen muscles of back, legs and shoulders.

\section{Block "Prophylaxis of flat-footedness" (10 minutes)}

Initial position (i.p.) is sitting on gymnastic bench. Seize basketball ball with feet and throw it (12-15 times).

I.p. is sitting on gymnastic bench; rolling of small ball by foot (50-60 sec. by each foot).

I.p. is sitting on gymnastic bench; bending and unbending of feet quickly (20-30 sec.).

I.p. is sitting, resting on floor by hands; rolling of ball by inner feet arches.

I.p. is standing on knees with hands on waist. Sit on heels 10-12 times.

I.p. is standing by gymnastic wall. Walk on the spot highly raising thigh and bending foot in sole.

I.p is standing with hands on waist. Walk on the spot keeping contact of toes with floor (up to $60 \mathrm{sec}$.).

I.p. is sitting position with hands on floor. Actively bend and unbend feet (by 18-20 times).

Jumps on the spot with little moving forward on tip-toes (up to 1 minute).

Balancing on filled ball - up to 1 minute.

Complex 3

Block "General physical training” (45 minutes)

At first stages of training the quantity of exercises can be reduced; the, with improvement of physical fitness it can be increased.

Run and jumps on the spot; with moving with additional weight (in different directions and with different amplitude, from different initial positions).

Hanging on arms, move forward.

Carrying of moderate loads on back with maximal speed.

Repeated up to 20 meters' run with additional weight and maximal speed.

Outdoor games of power orientation (for example improvised basketball with filled ball).

Chin ups on gymnastic bar.

Squatting with different temp and different initial positions; on one or two feet.

Jumps in depth by method of "strike training".

Long and high jumps from the spot and from run.

Jumps in half squat position in different directions (face, back, right or left side forward).

High jumps with catching hanged objects.

Jumps on one or two feet, moving forward by circle, by "snake", on the spot with turn.

Skipping (or with shortened skipping rope) on the spot and in movement.

Pressing ups in lying position.

Bending of stretched legs in hanging on arms position.

Torso bending in position lying on back, on abdomen.

Jumping down from pedestal of 40-60 cm height.

Exercises on gymnastic bar.

Walking in deep squat.

Shuttle run $(5 \times 6)$ with touching floor with hand.

Climbing rope by 2-3 meters' height.

\section{Complex 4}

Block "Prophylaxis of cold" (5 minutes)

Exercises for neck consist of three movements:

1. In standing position relax neck and sharply turn head ftp the right and to the left. Repeat 5-25 times;

2. In standing position drop head sharply forward and backward for 5-25 times;

3. In standing position bend head to the right and to the left (5 times). Breathe normally, When bending try to keep shoulders unmovable. After some time you will be able to put ear on shoulder.

This exercise strengthens neck muscles; relaxes in case of tonsillitis, pharyngitis, makes voice louder, eliminates speech defects.

Hatha Yoga exercises (25 minutes):

Triangle: from main stance part feet wider than shoulders by jump. Raise arms aside at shoulder level with palms downwards. Turn right and left feet to the right - left leg is stretched. Bend torso to the right and touch right ankle with right palm (possible to place right palm on the floor). Stretch left arm upwards. Keep posture for 30-40 seconds. Breathing shall be even and deep. Take initial position and fulfill the exercise to other side. This exercise increase hip joints and backbone's mobility; expands chest.

Forward bent from lying position: lie on back, keep feet together. Slowly take sitting position, bend forward as low as possible. Seize ankles. Drop head and relax. Keep posture about 20 seconds. Come out of posture: first sit upright 
and then, lie on back. Place arms along torso with palms upward. Feet are a little apart. This posture is favorable for back part of legs and abdomen muscles.

Forward bent from standing position: take main stance. Close palms behind back. Raise palms upward up to upper back at blades' level. Put feet wider than shoulders. Bend torso forward to right knee. Keep this posture for 20-30 seconds with normal breathing. Turn to initial stance, removing palms from behind the back. If it is difficult to close hands behind back, it is possible to seize wrist and then continue other movements. This exercise strengthens back and legs' muscles, increase mobility in girdle.

Birch (stand on shoulders): lie on back, arms are along torso with palms down. Raise both straightened in knees legs, until they will be behind head. Bend arms in elbows and place palms on back. The, slowly raise legs, feet towards ceiling. Legs and torso shall make straight line and chin - pressed to chest. Keep this position 15-30 sec. without over tension. Then slowly low legs and place arms on floor, palms down. This exercise is favorable for central nervous system, blood vessels; increases resistance to cold.

Block "psycho-regulation" (15 minutes)

Relaxation lying posture: lie on back with feet at about $40 \mathrm{~cm}$ width. Head touches floor, palms - upward and arms are at little distance from torso. Close eyes and relax. Breathe rhythmically. Then breathing will become light and slow. Concentrate on deep and light exhales. Keep this position 3-5 minutes.

Stand on shoulders (birch): Birch (stand on shoulders: lie on back, arms are along torso with palms down. Raise both straightened in knees legs, until they will be behind head. Bend arms in elbows and place palms on back. The, slowly raise legs, feet towards ceiling. Legs and torso shall make straight line and chin - pressed to chest. Keep this position 15$30 \mathrm{sec}$. without over tension. Then slowly low legs and place arms on floor, palms down. This exercise is favorable for central nervous system, blood vessels; increases resistance to cold.

Stand on one leg: stand upright with feet parted by approximately $40 \mathrm{~cm}$. Stretch arms forward, hands are relaxed, hanging down. Bend legs in knees and squat a little. Imagine that you are sitting in invisible armchair. Keep posture as long as possible. Upper part of legs will be tensed. It is an excellent exercise for legs and back's muscles, as well as for handsome carriage and self-confidence.

Lying rest posture: lie on back with feet at about $40 \mathrm{~cm}$ width. Head touches floor, palms - upward and arms are at little distance from torso. Close eyes and relax. Breathe rhythmically. Then breathing will become light and slow. Concentrate on deep and light exhales. Keep this position 3-5 minutes.

Statistical analysis: we used commonly known methods of transformation of questioning empiric data [23]. With the help of logical procedures we revealed correlations of the studied variables and determined mean statistic indicators of boys and girls' physical fitness at the beginning and at the end of academic year. Confidence of differences was determined by Student's t-criterion and significance level (p).

\section{Results}

\section{Substantiation of physical education system's effectiveness}

Assessment of students' motor fitness

For assessment of effectiveness of the worked out education system' content we fulfilled estimation of main motor qualities. In table 1 we present mean statistic data of students' physical fitness at the beginning and at the end of pedagogic experiment. Data analysis showed that most of the studied indicators witness about increase of results, comparing with initial data $(\mathrm{p}<0.05)$. Exclusions were results of 30 meters' run, in which no confident differences were found.

Table 1. Indicators of students' motor fitness at the beginning and at the end of pedagogic experiment $(M \pm m)$

\begin{tabular}{llllll}
\hline Indicators & Testing & & \multirow{2}{*}{ Differences } & \multicolumn{2}{c}{ Confidence of differences } \\
& Initial & Final & & p \\
\hline 30 meters' run, sec. & $7.2 \pm 0.14$ & $7.0 \pm 0.15$ & 0.2 & 0.97 & $>0.05$ \\
Shuttle run 3 x 10 m, sec. & $10.65 \pm 0.14$ & $10.2 \pm 0.16$ & 0.45 & 2.12 & $<0.05$ \\
Long jump, cm & $130.6 \pm 1.95$ & $137 \pm 2.39$ & 6.4 & 2.07 & $<0.05$ \\
Chin ups, q-ty of times & $10.7 \pm 0.27$ & $12.1 \pm 0.62$ & 1.4 & 2.07 & $<0.05$ \\
Bending, cm & $8.9 \pm 0.62$ & $11 \pm 0.8$ & 2.1 & 2.07 & $<0.05$ \\
Run during 6 minutes & $1203.2 \pm 81.4$ & $1474.4 \pm 89.6$ & 271.2 & 2.24 & $<0.05$ \\
\hline
\end{tabular}

Assessment of students' physical metric indicators

In table 2 we give mean statistical data of students' physical metric indicators at the beginning and at the end of pedagogic experiment. At the end of pedagogic experiment in the studied indicators we registered statistically confident $(p<0.05)$ improvements, comparing with initial data. Exclusions were results of body length and mass, in which no differences were found. 
Table 2. Indicators of students' physical metric parameters at the beginning and at the end of pedagogic experiment $(\mathrm{M}+\mathrm{m})$

\begin{tabular}{llllll}
\hline Indicators & Testing & & \multirow{2}{*}{ Confidence of differences } \\
& Initial & Final & Differences & t & p \\
\hline Body length, cm & $159.0 \pm 1.23$ & $160.5 \pm 0.8$ & 1.5 & 1.02 & $>0.05$ \\
Body mass, cm & $57.0 \pm 0.89$ & $56.9 \pm 0.89$ & 0.1 & 0.08 & $>0.05$ \\
Chest circumference, cm & $100.8 \pm 1.12$ & $104.1 \pm 0.97$ & 3.3 & 2.23 & $<0.05$ \\
Vital capacity of lungs, I & $3300 \pm 31.67$ & $3398 \pm 28.45$ & 93.0 & 2.18 & $<0.05$ \\
Right hand dynamometry, $\mathrm{kg}$ & $47.9 \pm 0.79$ & $49.9 \pm 0.53$ & 2 & 2.1 & $<0.05$ \\
Left hand dynamometry, $\mathrm{kg}$ & $47.0 \pm 0.79$ & $49.1 \pm 0.53$ & 2.1 & 2.21 & $<0.05$ \\
\hline
\end{tabular}

Assessment of interest to physical culture practicing and formation of healthy life style skills (see table 3).

Table 3. Indicators of students' interest to physical culture practicing and formation of healthy life style skills (points) $(\mathrm{M} \pm \mathrm{m})$

\begin{tabular}{llllll}
\hline Indicators & $\begin{array}{l}\text { Testing } \\
\text { Initial }\end{array}$ & Final & Differences & $\begin{array}{l}\text { Confidence of differences } \\
\text { t }\end{array}$ & p \\
\hline Interest to physical culture practicing, points & $4.01 \pm 0.1$ & $4, .41 \pm 0.1$ & 0.40 & 2.83 & $<0.01$ \\
Formation of healthy life style skills, conv. un. & $8.4 \pm 0.6$ & $20.9 \pm 2.8$ & 12.5 & 4.37 & $<0.001$ \\
\hline
\end{tabular}
practicing

After pedagogic experiment we found confident $(\mathrm{p}<0.01)$ increase of students' interest to physical culture Assessment of healthy life style skills' formation resulted in the following: total data showed statistically confident increase $(\mathrm{p}<0.001)$ of healthy life style skills' formation (see table 3 ).

Assessment of significant for studying indicators

These indicators were combined as far as we found no statistically confident differences between them (see table 4).

Table 4. Indicators of students' pedagogic characteristics $(M+m)$

\begin{tabular}{llllll}
\hline Indicators & Testing & & \multirow{2}{*}{ Differences } & \multicolumn{2}{c}{ Confidence of differences } \\
& Initial & Final & & t & p \\
\hline Interest to studying & $2.14 \pm 0.1$ & $2.47 \pm 0.1$ & 0.33 & 2.33 & $<0.05$ \\
Mental workability & $2.25 \pm 0.1$ & $2.56 \pm 0.1$ & 0.31 & 2.19 & $<0.05$ \\
Aggressiveness & $2, .28 \pm 0.1$ & $2.15 \pm 0.1$ & 0.13 & 0.92 & $>0.05$ \\
Emotional stability & $2, .97 \pm 0.1$ & $3.26 \pm 0.1$ & 0.29 & 2.05 & $<0.05$ \\
Concentration of attention & $2, .76 \pm 0.1$ & $3.06 \pm 0.1$ & 0.30 & 2.12 & $<0.05$ \\
Diligence & $2, .81 \pm 0.1$ & $3.11 \pm 0.1$ & 0.30 & 2.12 & $<0.05$ \\
\hline
\end{tabular}

After pedagogic experiment we found that practically all studied indicators were on higher, statistically confident $(\mathrm{p}<0.05)$ formation level. Exclusion was indicator of aggressiveness, in which differences between groups were not confident.

Assessment of socially significant qualities

Socially significant indicators of different age groups were combined as far as there were found no statistically confident differences between them (see table 5).

Table 5. Socially significant qualities of students $(M \pm m)$

\begin{tabular}{llllll}
\hline \multirow{2}{*}{ Indicators } & Testing & & \multirow{2}{*}{ Differences } & \multicolumn{2}{c}{ Confidence of differences } \\
& Initial & Final & & $\mathbf{p}$ \\
\hline Activity of moral position & $3.04 \pm 0.1$ & $3.36 \pm 0.1$ & 0.32 & 2.26 & $<0.05$ \\
Collectivism & $3.16 \pm 0.1$ & $3.47 \pm 0.1$ & 0.31 & 2.19 & $<0.05$ \\
Civic consciousness & $3.24 \pm 0.1$ & $2.51 \pm 0.1$ & 0.27 & 1.91 & $>0.05$ \\
Diligence & $3.30 \pm 0.1$ & $3.61 \pm 0.1$ & 0.31 & 2.19 & $<0.05$ \\
Creative activity & $3.42 \pm 0.1$ & $3.74 \pm 0.1$ & 0.32 & 2.26 & $<0.05$ \\
Will quality & $3.38 \pm 0.1$ & $3.69 \pm 0.1$ & 0.31 & 2.19 & $<0.05$ \\
\hline
\end{tabular}

At the end of pedagogic experiment most of socially significant qualities (with the exclusion of civic consciousness quality, in which no differences were found) were statistically confident $(\mathrm{p}<0.05)$ were formed better. 


\section{Discussion}

Results of our researches supplement the data of other authors about demand in formation of students' healthy life style [13] and their self cognition of their psycho-physical and motor potentials [4]. It should be noted that results of many researches $[1,19]$ to larger extent are oriented on socialization of students with health problems in conditions of educational medium. Our previous works $[15,27]$ also point that $t$ is possible to apply the worked out approaches to students of this category.

Significance of students' psycho-physical indicators of health can be one of the most important components in formation of their behavior style in social medium of universities. In this aspect our results are in good agreement with opinion of Gherissi A. Et al. [30] about specificities of realization of national holistic strategy of social constructivist model of students' education. Our previous researches point at worsening of higher educational students' physical, psychic and social moral health [2]. Results of our present research continue solution of this problem. Mc Sharry P. and Timmins F. [38] note significance of behavioral model, which permits for students to master stress control skills. It is especially important for first year students for their successful adaptation to educational medium. Results of our research point that it is possible to strengthen physical, psychic and social-moral health through creation of individualized behavior system.

Analysis of the received results permitted to determine that students indicators before and after pedagogic experiment differ statistically confidently. Effectiveness of the worked out system is proved by the following: confident differences of physical fitness before and after pedagogic experiment, statistically confident advantage by most of physical metric indicators, confident increase of interest to physical culture practicing and formation of healthy life style skills.

It is interesting that change of different personality's features is rather long process, which in some aspects resist to changes. We found statistically confident changes in such parameters as socially significant qualities of person, indicators of pedagogic characteristics. It points at rather adequate and effective means and methods, used in our research. Such approach permits to achieve real positive changes of psychic and social-significant qualities of higher educational establishments' students within one academic year.

\section{Conclusions}

Thus, content of additional (health related) physical culture training implies list of knowledge, skills and abilities. Prevailing orientation of such training shall be directed on solution of health related, general developing and recreational tasks. With it, attention of first priority shall be paid to formation of physical, psychic and social-moral health. Application of non traditional health related means, like Hatha Yoga, in physical education system will also be effective. Very important is ability to consciously form healthy life style skills. It permits to strength and deepen professional fitness at the account of activation of creative abilities, releasing of additional time due to rhythmic organization and structuralizing of educational process.

Results of the conducted researches supplement theory and methodic of students' physical education with new ideas about upgrading of educational process. The basis of such process is implementation of personality oriented system of students' physical, psychic and social-moral health strengthening.

\section{References}

1. Adyrkhaev SG. Modern technology of physical education of disabled students in conditions of inclusive education. Pedagogics, psychology, medical-biological problems of physical training and sports, 2016;1:4-12. doi:10.15561/18189172.2016.0101

2. Ajengar B.K.S. Pranaiama. Iskusstvo dykhaniia [Pranayama. The art of breathing]. Kiev: Sofia; 1995. (in Russian)

3. Baskevich OV. Interconnection of students' somatic type with somatic health. Physical Education of Students, 2015;6:4-9. doi:10.15561/20755279.2015.0601

4. Bessarabova IuV, Khar'kovskaia EV. Formirovanie psikhofizicheskikh kachestv studentov s ogranichennymi vozmozhnostiami zdorov'ia i invalidov v processe fizicheskogo vospitaniia [Formation of disabled students' psychophysical qualities in physical education process]. Istoricheskaia i social'no-obrazovatel'naia mysl', 2016;51:23-26. (in Russian)

5. Borisova NIu. Social'noe zdorov'e obshchestva i neobkhodimost' reformirovaniia obrazovaniia [Social health of society and demand in reformation of education]. IV Vserossijskaia nauchno-prakticheskaia konferenciia "Obrazovanie $i$ zdorov'e" (ss. 48-49) [4 ${ }^{\text {th }}$ All Russian scientific-practical conference "Education and health"], Kaluga. 1998. P. 48-49. (in Russian)

6. Vazhenin CA. Koncepciia razvitiia lichnostno orientirovannoj sistemy fizicheskoj kul'tury i sporta v Leningradskoj oblasti [Conception of development of personality-oriented physical culture and sports system in Leningradskaya region]. Teoriia i praktika fizicheskoj kul'tury, 2006;3: 12-14. (in Russian)

7. Volkov BS, Volkova NV. Metody issledovanij v psikhologii [Methods of researches in psychology]. Moscow: Pedagogical Society of Russia; 2002. (in Russian)

8. Galimov GY, Kuzmin VA, Kudryavtsev MD, Kopylov YuA, Gaskov AV, Strelnikov VA. Peculiarities of formation of students-boxers' socially significant qualities as the basis of their future professional functioning. The Buryat State University Bulletin, 2014;13:68-72.

9. Gas'kov AV, Galimov GIa, Kuzmin VA, Kudriavcev MD, Kopylov YuA, Strelnikov VA. Osobennosti formirovaniia social'no znachimykh lichnostnykh kachestv studentov-bokserov kak osnovy budushchej professional'noj deiatel'nosti [Peculiarities of formation of students-boxers' socially significant qualities as the base of future professional functioning]. The Buryat State University Bulletin, 2014;1:68-71. (in Russian) 
10. Golovina LL, Kopylov YuA, Polianskaia NV. Psikhologo-pedagogicheskie pokazateli uchashchikhsia srednego shkol'nogo vozrasta [Psychological-pedagogic indicators of middle school age pupils]. Fizicheskaia kul'tura: vospitanie, obrazovanie, trenirovka, 2009;3:20-22. (in Russian)

11. Zubkov AN, Ochapovskij AP. Khatkha-joga dlia nachinaiushchikh [Hatha-Yoga for beginners], Moscow: Medicine; 1991. (in Russian)

12. Ionova OM. Salutogenetic approach to professional training of future teachers. Pedagogics, psychology, medicalbiological problems of physical training and sports, 2015;2:34-42. doi:10.15561/18189172.2015.0206

13. Ismiianov VV. Zhizneustrojstvo studentov-sirot na osnove formirovaniia psikhofizicheskogo zdorov'ia sredstvami fizicheskogo vospitaniia [Living arrangement of students-orphans on the base of psycho-physical health formation by means of physical education]. Uchenye zapiski universiteta im. P.F. Lesgafta, 2015;11(129): 107-110. (in Russian)

14. Kokova EI, Kopylov YuA. Polivariantnye fizkul'turno-ozdorovitel'nye meropriiatiia dlia oslablennykh studentov [Poly-variant health related physical culture measures for weakened students]. Mezhdunarodnaia nauchnoprakticheskaia konferenciia "Molodaia sportivnaia nauka Belarusi", Minsk, 8-10 apr. 2014 g. [International scientific-practical conference "Young sport science of Belarus", Minsk, April 8th- 10th, 2014], Minsk: BGUFK; 2014;2: P. 145-146.

15. Kopylov YuA, Jackowska LN, Kudryavtsev MD, Kuzmin VA, Tolstopyatov IA, Iermakov SS. The concept of structure and content of health related trainings for higher educational establishments' students. Physical Education of Students, 2015;5:23-30. doi:10.15561/20755279.2015.0504

16. Kuzmin VA, Kudryavtsev MD, Kopylov YuA, Galimov IG, Strelnikov VA. Konceptual'nye osnovy neobkhodimosti obnovleniia dopolnitel'nogo ozdorovitel'nogo fizicheskogo vospitaniia studentov [Conceptual principles of demand in students' health related physical education's renewal]. Mezhdunarodnaia nauchno-prakticheskaia konferenciia "Molodaia sportivnaia nauka Belarusi", Minsk, 8-10 apr. 2014 g. [International scientific-practical conference "Young sport science of Belarus", Minsk, April 8th- 10th, 2014], Minsk: BGUFK;.]. 2014; 2 P. $162-165$ (in Russian)

17. Kuzmin VA, Kopylov YuA, Kudryavtsev MD, Galimov GY, Iermakov SS. Substantiation of effectiveness of trainings on health related methodic for students with weakened motor fitness. Physical Education of Students, 2015;6:43-49. doi:10.15561/20755279.2015.0606

18. Landa BKh. Metodika kompleksnoj ocenki fizicheskogo razvitiia i fizicheskoj podgotovlennosti [Methodic of physical condition and physical fitness complex assessment]. Moscow: Soviet sport; 2004 (in Russian)

19. Liashenko VN, Tumanova VN, Hatsko EV. Study of personality's temperament and self-assessment of higher educational establishments' students. Physical Education of Students, 2016;2:19-23. doi:10.15561/20755279.2016.0203

20. Motkov IO. Prakticheskoe rukovodstvo po samoanalizu lichnosti [Practical guide for personality self analysis]. Moscow; 1993. (in Russian)

21. Opletin AA, Panachev VD. Samorazvitie lichnosti studenta sredstvami pedagogicheskogo autotreninga na zaniatiiakh fizicheskoj kul'turoj [Self development of student's personality by means of pedagogic auto-training at physical culture lessons]. Pedagogiko-psikhologicheskie i mediko-biologicheskie problemy fizicheskoj kul'tury $i$ sporta, 2015;2(35): 133-140. (in Russian)

22. Osipov AIu, Pereus OV, Starova OV, Fukalova AO. Povyshenie effektivnosti zdorov'esberegaiushchej deiatel'nosti $\mathrm{v}$ vedushchikh universitetakh Krasnoiarskogo kraia [Increase of effectiveness of health related activity in leading universities of Krasnoyarskiy region]. Problemy sovremennogo pedagogicheskogo obrazovaniia, 2016;50(3):117123. (in Russian)

23. Paniotto VI, Maksimenko VS. Kolichestvennye metody v sociologicheskikh issledovaniiakh [Quantitative methods in sociological researches], Kiev; 2003. (in Russian)

24. Pichurin VV. Psychological and psycho-physical training as a factor of personal anxiety at students. Pedagogics, psychology, medical-biological problems of physical training and sports, 2015;3:46-51. doi:10.15561/18189172.2015.0307

25. Sadov, V.Iu. (2001). Teoretiko-metodicheskie osnovy zdorovogo obraza zhizni uchashchejsia molodezhi [Theoretical-methodic principles of students' healthy life style], Sankt Petersburg; Petropolis. (in Russian)

26. Salatenko IO, Dubinskaya OYa. Psycho-physical perfection of economic specialties' girl students under influence of sport-oriented technology, based on prevalence of volleyball practicing. Pedagogics, psychology, medical-biological problems of physical training and sports, 2015;12:103-108. doi:10.15561/18189172.2015.12016

27. Skurikhina NV, Kudryavtsev MD, Kuzmin VA, Iermakov SS. Fitness yoga as modern technology of special health groups' girl students' psycho-physical condition and psycho-social health strengthening. Physical Education of Students, 2016;2:24-31. doi:10.15561/20755279.2016.0204

28. Bliznevsky A, Kudryavtsev M, Kuzmin V, Tolstopyatov I, Ionova O, \& Yermakova T. Influence of personal characteristics of pupils and students on the effectiveness of the relationship to the specific physical activities. Journal of Physical Education and Sport, 2016;16(2):424-432. doi:10.7752/jpes.2016.02066

29. Bliznevsky AA, Kudryavtsev MD, Iermakov SS, Jagiełło W. Formation of active-effective attitude of 12-13 years' judo athletes to sports functioning in competition period. Archives of Budo, 2016;12:101-115.

30. Gherissi A, Tinsa F, Soussi S, \& Benzarti A. Teaching research methodology to student midwives through a socioconstructivist educational model: The experience of the high school for science and health techniques of Tunis. Special Education Section, 2016;33:46-48. doi:10.1016/j.midw.2015.10.015

31. Iermakov S, Podrigalo L, Romanenko V, Tropin Y, Boychenko N, Rovnaya O, \& Kamaev O. Psycho-physiological features of sportsmen in impact and throwing martial arts. Journal of Physical Education and Sport, 2016;16(2): 433441. doi:10.7752/jpes.2016.02067

32. Ivashchenko O, Khudolii O, Yermakova T, Iermakov S, Nosko M, \& Nosko Y. Factorial and discriminant analysis as methodological basis of pedagogic control over motor and functional fitness of 14-16 year old girls. Journal of Physical Education and Sport, 2016;16(2): 442-451. doi:10.7752/jpes.2016.02068

33. Kara B, \& İscan B. Predictors of Health Behaviors in Turkish Female Nursing Students. Asian Nursing Research, 2016;10(1):75-81. doi:10.1016/j.anr.2015.12.001 
34. Khudolii OM, Iermakov SS, \& Ananchenko KV. Factorial model of motor fitness of junior forms' boys. Journal of Physical Education and Sport, 2015;15(3), 585-591. doi:10.7752/jpes.2015.03088

35. Kozina Z, Repko O, Ionova O, Boychuk Y, \& Korobeinik V. Mathematical basis for the integral development of strength, speed and endurance in sports with complex manifestation of physical qualities. Journal of Physical Education and Sport, 2016;16(1):70-76. doi:10.7752/jpes.2016.01012

36. Kozina ZL, Iermakov SS, Kuzmin VA, Kudryavtsev MD, \& Galimov GJ. Change of cortisol and insulin content in blood under influence of special workability recreation system for students with high motor functioning level. Research Journal of Pharmaceutical, Biological and Chemical Sciences, 2016;7(2), 1068-1077.

37. Kuzmin VA, Kopylov YA, Kudryavtsev MD, Tolstopyatov IA, Galimov GY, \& Ionova OM. Formation of professionally important qualities of students with weakened motor fitness using a health related and sport-oriented training program. Journal of Physical Education and Sport, 2016; 16(1): 136-145. doi:10.7752/jpes.2016.01023

38. Mc Sharry P, \& Timmins F. An evaluation of the effectiveness of a dedicated health and well being course on nursing students' health. Nurse Education Today, 2016; 44: 26-32. doi:10.1016/j.nedt.2016.05.004

39. Pomeshchikova IP, Shevchenko OO, Yermakova TS, Paievskyi VV, Perevoznyk VI, Koval MV, . . . Moiseienko OK. Influence of exercises and games with ball on coordination abilities of students with disorders of muscular skeletal apparatus. Journal of Physical Education and Sport, 2016;16(1), 146-155. doi:10.7752/jpes.2016.01024

40. Pryimakov O, Iermakov S, Kolenkov O, Samokish I, \& Juchno J. Monitoring of functional fitness of combat athletes during the precompetitive preparation stage. Journal of Physical Education and Sport, 2016;16(2), 551-561. doi:10.7752/jpes.2016.02087

\begin{tabular}{|c|}
\hline Information about the authors: \\
\hline $\begin{array}{l}\text { Kudryavtsev M.D.; http://orcid.org/0000-0002-4377-0879; } \\
\text { kumid@yandex.ru; Siberian Federal University (SibFU); } 79 \\
\text { Svobodny pr., Krasnoyarsk, 660041, Russia; Siberian State } \\
\text { Aerospace University; Office A-406, 31, Krasnoyarsky Rabochy Av., } \\
\text { 660014, Krasnoyarsk, Russia. }\end{array}$ \\
\hline $\begin{array}{l}\text { Kopylov Yu.A.; http://orcid.org/0000-0002-3925-0483; } \\
\text { yuko.47@mail.ru; The Federal State Scientific Institution of Russian } \\
\text { Academy of education "The Institute of Age Physiology" } \\
\text { Pogodinskaya st., 8, k. 2, Moscow, 119121, Russia. }\end{array}$ \\
\hline 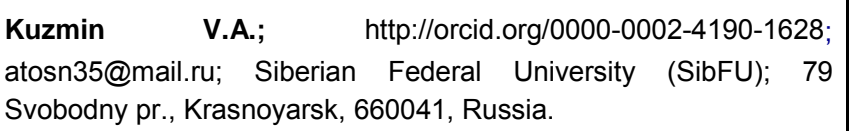 \\
\hline $\begin{array}{l}\text { lonova } \quad \text { O.M.; } \quad \text { http://orcid.org/0000-0003-0445-9030; } \\
\text { ionova_54@mail.ru; H.S. Skovoroda Kharkiv National Pedagogical } \\
\text { University; Artema str. 29, Kharkov, 61002, Ukraine. }\end{array}$ \\
\hline $\begin{array}{l}\text { Yermakova T.S.; http://orcid.org/0000-0002-3081-0229; } \\
\text { yermakova2015@gmail.com; H.S. Skovoroda Kharkiv National } \\
\text { Pedagogical University; Artema str. 29, Kharkov, 61002, Ukraine. }\end{array}$ \\
\hline $\begin{array}{l}\text { Cite this article as: Kudryavtsev M.D., Kopylov Yu.A., Kuzmin } \\
\text { V.A., Ionova O.M., Yermakova T.S. Personality oriented system } \\
\text { of strengthening of students' physical, psychic and social-moral } \\
\text { health. Physical education of students, 2016;3:43-52. } \\
\text { doi:10.15561/20755279.2016.0306 }\end{array}$ \\
\hline $\begin{array}{l}\text { The electronic version of this article is the complete one and can be found } \\
\text { online at: http://www.sportpedu.org.ua/html/arhive-e.html }\end{array}$ \\
\hline $\begin{array}{l}\text { This is an Open Access article distributed under the terms of the Creative } \\
\text { Commons Attribution License, which permits unrestricted use, distribution, } \\
\text { and reproduction in any medium, provided the original work is properly cited } \\
\text { (http://creativecommons.org/licenses/by/4.0/deed.en). }\end{array}$ \\
\hline $\begin{array}{l}\text { Received: 06.06.2016 } \\
\text { Accepted: 26.06.2016; Published: } 28.06 .2016\end{array}$ \\
\hline
\end{tabular}

